\title{
BAUDELAIRE: PROLEGÔMENOS A TODA BIOGRAFIA EXISTENCIAL SARTREANA FUTURA
}

\author{
Gustavo Fujiwara ${ }^{1}$ \\ Universidade Federal de São Paulo (UNIFESP) \\ (i) http://orcid.org/0000-0002-3971-9632 \\ E-mail: fujiwaragustavo@gmail.com
}

\section{RESUMO:}

Neste artigo pretendemos analisar a maneia pela qual o filósofo francês Jean-Paul Sartre modaliza, a partir da psicanálise existencial elaborada em L'être et le néant (1943), sua biografia existencial sobre o poeta Charles Baudelaire. Em Baudelaire (1947), seremos capazes de localizar os prolegômenos a toda biografia existencial sartreana futura, isto é, o modus operandi de investigação/escrita biográfica de Sartre.

PALAVRAS-CHAVE: Biografia existencial; Psicanálise existencial; Ontologia fenomenológica; Liberdade.

\section{BAUDELAIRE: PROLEGOMENA TO ANY FUTURE SARTRE'S EXISTENTIAL BIOGRAPHY}

\section{ABSTRACT:}

The aim of this article is to analyze the way the French philosopher Jean-Paul Sartre modalizes, through the existential psychoanalysis elaborated in L'être et le néant (1943), his existential biography about the poet Charles Baudelaire. In Baudelaire (1947), we will be able to locate the prolegomena to any future existential biography, therefore, Sartre's modus operandi of biographical research/writing.

KEYWORDS: Existential biography; Existential psychoanalysis; Phenomenological ontology; Liberty.

\footnotetext{
${ }^{1}$ Doutor em Filosofia pela Universidade Federal de São Paulo (UNIFESP), Guarulhos - SP, Brasil. Agência de financiamento: FAPESP, processo número: 2014/09973-4

FUJIWARA, Gustavo. Baudelaire: prolegômenos a toda biografia existencial sartreana futura. Griot : Revista de Filosofia, Amargosa - BA, v.18, n.2, p.233-259, dezembro, 2018. 
Baudelaire, escrito um ano depois de L'être et le néant ${ }^{2}$, fora inicialmente publicado como introdução aos Écrits intimes de Baudelaire (1946) antes de formar um volume separado nos anos 1947. Primeiro escrito a buscar operar a partir da engenharia da psicanálise existencial, a presente obra na qual realizaremos uma incursão investigativa pretende mostrar, em linhas gerais, que Baudelaire, longe de ser um "poeta maldito" 3, como pensam, por exemplo, muitos críticos literários ou biógrafos, teve a vida que mereceu: sob este esteio, tratar-se-á de revelar, a partir do método da psicanálise existencial, a escolha original do poeta (escolha de si mesmo) e, em seguida, "expor as diversas condutas que derivam desta escolha (antinaturalismo, logo, recusa da inspiração e elogio da maquiagem, culto da frigidez, dandismo como reação à desclassificação do escritor, passadismo, espiritualismo)" (LOUETTE, 2013, p. 55) ${ }^{4}$. Ora, o filósofo demonstrará que é a partir de uma escolha original/primeira em relação ao Ser que todas as demais condutas empíricas do poeta recebem uma significação; nesse sentido, é preciso indicar a interdependência de cada uma de suas condutas: "para Sartre, que escolheu como fim tangível à sua atividade de construir uma filosofia da liberdade, trata-se essencialmente de desvelar, do que é conhecido do personagem Baudelaire, sua significação: a escolha de si mesmo que ele fez" (LEIRIS, 2012, p. 13); e esta "escolha de si mesmo" não será outra senão a própria liberdade do poeta frente à sua situação singular. Este ensaio ergue-se contra a doxa (poeta maldito que fora acometido injustamente pela má sorte) e pretende indicar, no plano moral, a responsabilidade/cumplicidade de Baudelaire em relação à sua má fortuna; n'outras palavras, é preciso revelar, junto com a escolha original de si mesmo, a liberdade sem desculpas do autor de Fleurs du Mal (1857): é indefectível, portanto, que Baudelaire tenha seguido os fios teóricos da ontologia fenomenológica dos anos 1943 e, mais especialmente, a psicanálise existencial.

Destarte, façamos da indagação de Sartre a nossa: "se, ao contrário das ideias recebidas, os homens não tivessem jamais senão a vida que mereceram?" (SARTRE, 2012, p. 18). Sabemos, en passant, que a escolha fundamental de Baudelaire é livre escolha de si diante do problema do Ser ${ }^{5}$, e se esta escolha modaliza, isto é, significa todas as suas demais atitudes observáveis, que escolha original de si, finalmente, seria esta? Busquemo-la; mas a partir de quais conceitos? Pois bem, esta pergunta é o ensejo para que possamos, numa espécie de primeiro contato, compreender e definir o que significa, em termos sartreanos, escrever uma biografia existencial; para tanto, não nos furtemos aqui de citar o capítulo "La dialectique dans la biographie", do excelente livro de Jean-François Louette, Silences de Sartre. Na referida obra, o comentador, com sagacidade, mostrará que a concepção biográfica em Sartre somente é possível a partir da instituição teórica, em $E N$, do projeto de ser/escolha original; e dessa tópica, indicar-se-á a passagem da

\footnotetext{
${ }^{2}$ Doravante abreviado como $E N$.

3 Logo, "nós estamos longe, por consequência, do Baudelaire vítima boa para os biógrafos piedosos ou condescendentes e não é uma vida de santo, mas uma descrição de caso clínico que nos é proposto" (LEIRIS, 2012, p. 13).

${ }^{4}$ Poderíamos lembrar, ainda, seu culto à higiene e à vestimenta.

${ }^{5}$ É nesse sentido que podemos falar aqui em destino escolhido e não em destino passivamente sofrido; veremos este ponto no decorrer de nosso texto.
} 
ilusão biográfica à possibilidade da biografia. Mas o que isso significa? Para Louette, restituir a questão biográfica no corpus sartreano é ipso facto localizar a passagem do instantaneísmo de La transcendance de l'Ego/La Nausée ${ }^{6}$ à temporalidade ek-stática de $E N$ : ambos os primeiros escritos reduzem "o tempo "à pluralidade de instantes incomunicáveis', duplo obstáculo, ontológico e linguístico, à uma biografia que supõe um mínimo de continuidade temporal e sua expressão na escrita; doravante, "sob o plano ontológico (da temporalidade) ao tempo-instante opõem-se, desde 1939, o projeto, depois, a partir de 1945, a dialética" (LOUETTE, 2002, p. 202). A partir desta rápida - porém precisa - indicação, compreendemos que as noções de projeto/dialética são condições sine qua non para que possamos falar em biografia existencial. Pois bem, mas o que é uma biografia existencial? Em primeiro lugar, portanto, diremos que a biografia, em termos sartreanos, é um método de compreensão do sujeito, isto é, um método que, a partir da psicanálise existencial, visa desvelar o projeto/escolha original do para-si. Sobremaneira, importa fazer notar aqui que esta psicanálise, na escrita biográfica, opera impreterivelmente através de uma dialética: na medida em que o projeto irrompe como conceito que, ao mesmo tempo, conjuga duração e instante ${ }^{7}$, a dialética, tal como o projeto,

[...] pensa a continuidade e a descontinuidade do tempo. Como o projeto, a dialética integra e torna pensável (e que também pode ser escrito) a descontinuidade; ela é uma 'lógica da temporalidade'. Mas a dialética vai ainda mais longe que o projeto. Ela cerca melhor a dimensão histórica e intersubjetiva do e no homem; ela é, nesse sentido, mais coletiva. Mas ela é também mais individual: ela reflete melhor esta realidade-humana que Sartre obstinadamente apresenta como indizível (LOUETTE, 2002, pp. 207-208).

Se se fala da realidade-humana como indizível, isso significa que a consciência (de) si - presença a si -, o nível irrefletido do Cogito é, antes de um conhecimento, uma existência: "Sartre defende a tese da "intimidade silenciosa do Cogito', definido como 'presença a si sem intermediário, silêncio da consciência'. Do mesmo modo, Qu'est-ce que la littérature? sustenta que 'as maiores riquezas da vida psíquica são silenciosas" (LOUETTE, 2002, p. 209). Nesta toada, a biografia existencial, para dar voz a esta, digamos, face silenciosa do Cogito, deve produzir um tipo específico de análise/escrita (estilo) ${ }^{8}$; e este estilo, já adiantando-nos, será

\footnotetext{
${ }^{6}$ Sobre o romance La Nausée como romance anti-biográfico, ver "Désillusions biographiques dans La Nausée", na já citada obra de Louette. Além desta obra, sugerimos a leitura da apresentação da edição dedicada a Flaubert da revista Recherches \& Travaux, "L'Idiot de la famille de Jean-Paul Sartre". Nesta apresentação, Anselmini e Aucagne traçam a evolução, digamos assim, da biografia no corpus sartreano, isto é, restituem a história das diversas concepções de Sartre a despeito da biografia e de seu papel: da crítica do procedimento biográfico em $L a$ Nausée, passando pela ilusão biográfica dos Carnets de la Drôle de Guerre e, mais para frente, de sua reabilitação a partir de um esboço de biografia de Guilherme II, consta-se, a partir desta reabilitação, "a ocasião para esclarecer a situação presente, refletir a historicidade do indivíduo e, mais amplamente, os modos de compreensão e representação do evento histórico" (ANSELMINI, AUCAGNE, 2007, p. 11).

${ }^{7}$ Sobre este ponto, ver Louette, 2002, pp. 203-207.

${ }^{8}$ Lemos: "A linguagem é prosa por essência, e a prosa, por essência, fracasso; o ser se coloca diante de nós como uma torre de silêncio (...)" (SARTRE, 1979, p. 246). Assim, para Louette (2002, p. 208): "É tarefa do estilo reverter este fracasso".
} 
imantado pela dialética (dialética singular/dialética do indivíduo ${ }^{9}$ ) enquanto "movimento" capaz de totalizar as diversas significações (muitas vezes contraditórias entre si) de uma existência singular. Essas ligeiras observações tecidas, vejamos como projeto/dialética são colocados em marcha pela biografia existencial enquanto aplicação da psicanálise existencial sartreana; nesta toada, retomemos, en passant, os princípios cardeais da psicanálise existencial tal como esta fora esboçada na magnum opus dos anos 1943.

II

Em L'être et le néant a psicanálise existencial é esboçada já no final da obra enquanto método especial de elucidação de um existente singular em situação a partir de seus fins singulares-em-situação. Tendo isso em vista, a psicanálise existencial sartreana se propõe ser "um estudo e uma classificação desses fins", uma interrogação desse fim, "pois ele faz parte da subjetividade absoluta como seu limite transcendente e objetivo" (SARTRE, 2010, p. 602); ora, n'outras palavras, trata-se, neste momento, de elaborar um método que seria capaz de fazer vir à tona a escolha original do sujeito enquanto escolha de singularização de si diante dessa expectativa ontológica que figura como tentativa individual de realização da totalidade em-sipara-si ou Valor. Entrementes, este método é, segundo o Autor, deveras diferente dos métodos desenvolvidos e aplicados pelas psicologias empíricas, pois, ao contrário dessas, visa restituir a totalidade do sujeito sem recorrer ao princípio psicológico segundo o qual os desejos seriam pequenas entidades psíquicas habitando a consciência e cuja soma representaria o ápice de tais investigações: que o psicólogo não se limite ipso facto à soma desses desejos definidos como tendências, e passe, depois, a um tipo de análise que visa revelar o parentesco dessas tendências (conjunto de desejos empíricos ou tendências definido como organização sintética), isso não representa menos um erro de princípio, pois, incialmente, esta análise psicológica "parte do postulado de que um fato individual é produzido pela intersecção de leis abstratas e universais" (SARTRE, 2010a, p. 603). Se, por exemplo, o psicólogo empírico busca desvendar o indivíduo Flaubert, o fato a ser explicado, isto é, suas disposições literárias prematuras, será forçosamente enquadrado por uma combinação de desejos típicos a todo jovem, e, portanto, abstratos: o concreto aqui é somente esta combinação dos desejos/tendências, "o abstrato é, pois, por hipótese, anterior ao concreto e o concreto é apenas uma organização de qualidades abstratas; o individual é somente a intersecção de esquemas universais" (SARTRE, 2010, p. 603). Submerso neste princípio empírico substancialista, o psicólogo rejeita o individual puro em nome do abstrato, quer dizer, ele privilegia a realidade-humana qualquer (desejos que fazem parte do rol dos desejos dos jovens em geral) em detrimento à realidade-humana individual, ele reduz a subjetividade de Flaubert a um arrazoado de circunstâncias exteriores de sua vida: o jovem escreverá, pois a literatura foi o objeto no qual ele depositou sua ambição de

\footnotetext{
9 Esta dialética singular, também nomeada por Sartre como "dialética decapitada" (Situations, IV, p. 270), revela o movimento contraditório de uma existência, "onde não há outra síntese a não ser a antítese"; recusa de síntese, ela intensifica "o conflito do nada da consciência e do pleno do ser" (SIMONT, 2013, p. 136).
} 
grandiosidade e sua força; ambição e força que fazem parte, por seu turno, dos desejos dos adolescentes em geral.

Este método, para Sartre, deixa um hiato impossível de ser preenchido: por que, por exemplo, a ambição e o sentimento de força produzem no jovem Flaubert a exaltação mais do que uma espera tranquila ou uma impaciência? Por que, além disso, essa exaltação se específica em necessidade de agir e sentir em demasia? Por que, no lugar de buscar satisfazer-se em aventuras amorosas ou atos violentos, ele escolhe precisamente a satisfação simbólica da literatura? Esses e tantos outros hiatos marcam, na ótica sartreana, uma defasagem metodológica que galvaniza o modus operandi empírico da psicologia que se debruça em uma definição substancialista do desejo e dá por encerrado a sua investigação quando realiza a soma desses desejos convertidos em tendências: por exemplo, "apreenderemos o elo entre castidade e misticismo, entre fraqueza e hipocrisia; mas nós ignoramos a relação concreta entre esta castidade (esta abstinência em relação a tal ou tal mulher (...)) e o conteúdo individual do misticismo" (SARTRE, 2010, pp. 604-05). Esta metodologia psicológica operaria da mesma maneira que a psiquiatria, ciência para a qual a compreensão das estruturas gerais do delírio são mais importantes do que os conteúdos individuais e concretos desses delírios: para o filósofo, ao contrário, o mais profícuo seria (sem negar a importância das estruturas gerais, por exemplo, da psicose) indagar por qual razão (razão esta que remete, necessariamente, à escolha original enquanto projeto original de ser) este homem particular, este ser-no-mundo individual, crê ser tal personalidade histórica ao invés de tal outra ou por qual razão (igualmente ontológica) seu delírio de compensação se satisfaz com tais ideias de grandeza ao invés de se satisfazer com outras ideias. Aqui, vejamos, é possível depreender o tipo de investigação que almeja Sartre, qual seja: uma investigação que privilegie a individualidade concreta e situada do sujeito enquanto ser-no-mundo que se pessoaliza através de uma transcendência singular que expressa sua escolha original enquanto projeto original de ser sob a forma em-si-para-si ou Valor: nesta toada, esta singularidade/individualidade/pessoalidade, em nível de escolha/projeto original, não indica uma personalidade psicológica que seria sustentada pelo Ego em regime de esfera psíquica; não, muito pelo contrário, essa singularidade, enquanto objeto de análise da psicanálise da consciência, é singularidade de uma liberdade em situação de escolha, quer dizer, de uma liberdade que se escolha a si mesma diante do problema do Ser.

Assim, se o filósofo pretende compreender a especificidade desta psicose, ele deverá, em primeiro lugar, fazer uso dos ensinamentos ontofenomenológicos que asseveram que a relação do para-si ao mundo e aos outros é uma relação de tipo existencial que constitui este para-si como um ser-no-mundo; depois, ele deverá compreender que esta relação é ambígua e, desta ambiguidade mesma, podem surgem patologias que afetam o ser-no-mundo deste sujeito; imbuído neste método que visa esclarecer a individualidade concreta (a psicanálise existencial) do para-si, o filósofo passará, então, a uma análise que privilegie a singularidade deste ser-nomundo: compreender a escolha que este psicótico faz por este personagem histórico $\mathrm{X}$ ao invés de $\mathrm{Y}$ revela-se fundamental para que possamos desvelar a maneira singular e concreta na qual este ser-no-mundo se relaciona existencialmente com o Todo (com o em-si e com os outros, em suma, com o mundo). Este trânsito do universal ao 
concreto e do concreto ao universal (das estruturas ontofenomenológicas do real ao modo de individualização dessas estruturas pelo ser-no-mundo) visará, como veremos a propósito das biografias existências, superar o método da dialética materialista e o método psicanalítico ${ }^{10}$. Sem que nos adiantemos muito sobre este ponto (ponto que tocaremos quando de nossas análises acerca das referidas biografias existenciais), este exemplo da compreensão da psicose para além de suas estruturas gerais é revelador quanto ao tipo de investigação que Sartre pretende levar a cabo com a chamada psicanálise existencial:

O que nós exigimos - e que jamais tentam nos proporcionar - é, pois, um verdadeiro irredutível, isto é, um irredutível cuja irredutibilidade seria evidente para nós, e que não nos fosse apresentado como o postulado do psicólogo e o resultado de sua recusa ou incapacidade de ir mais longe, mas sim cuja constatação produzisse em nós um sentimento de satisfação. E esta exigência não deriva desta incessante perseguição da causa, desta regressão ao infinito que se costuma descrever como constitutiva da investigação racional (...). Não se trata da indagação infantil de um 'porquề que não permitisse nenhum 'por quê?' - mas, ao contrário, é uma exigência fundamentada em uma compreensão pré-ontológica da realidade-humana e na recusa, vinculada a tal compreensão, de considerar o homem como sendo analisável e redutível a dados primordiais, a desejos (ou 'tendências') determinados, suportados pelo sujeito como propriedades de um objeto. (...) Ora, o que cada um de nós exige em seu esforço mesmo para compreender o outro, é, incialmente, que não tenhamos jamais de recorrer a esta ideia de substância, inumana por estar aquém do humano. Depois, exigimos que o ser considerado não se dissolva em poeira e que possamos nele descobrir esta unidade - da qual a substância não passa de uma caricatura -, unidade que há de ser unidade (...) pessoal. Esta unidade, que é o ser do homem considerado, é livre unificação (SARTRE, 2010, pp. 606-607).

Deste longo e fundamental excerto repleto de exigências teóricas, somos capazes de depreender as diretrizes conceituais que irão fundamentar a démarche da psicanálise da consciência em $E N$ : recusando os princípios empíricos da psicologia em nome dos princípios ontofenomenológicos, veremos que ser, para todo para-si, é unificar-se no mundo, e a unificação irredutível que visamos aqui, unificação que é este para-si singular, é, portanto, a unificação de um projeto original, unificação que deve revelar-se como um absoluto não substancial, ponto último e nevrálgico para além do qual não podemos mais avançar, pois não é senão o ser mesmo do sujeito considerado. N'outras palavras, o existente humano singular deve ser abordado "em compreensão", pois possui a priori uma significação total que esclarece todas as condutas em nível ôntico. Finalmente, o filósofo exige um método capaz de encontrar, sob os aspectos incompletos e parciais do sujeito, a verdadeira concretude enquanto totalidade de seu elã rumo ao ser, sua relação original a si, ao mundo e ao outro, na unidade de relações internas de um projeto fundamental; este elã, aliás, somente pode ser concebido como individual e único enquanto expressão última deste ser-no-mundo: longe de apartarmo-nos da pessoa como fazem as análises psicológicas

${ }^{10}$ As biografias existenciais de Satre são concebidas a partir desta interrogação pontual: "o verdadeiro problema é: interpretação pela história de todos ou pela história de um só?, pelo método chamado de 'dialética materialista' ou pela psicanálise?" (SARTRE, 2016, p. 88). 
empíricas ao constituírem o individual pela mera soma de máximas genéricas, é preciso que descubramos, desvelemos, o projeto original que constitui a pessoa. Partindo desse princípio, seríamos capazes, para voltar ao exemplo de Flaubert, de encontrar, sob a necessidade de escrever e, sobretudo, de escrever estes livros em particular, a necessidade da atividade em geral enquanto projeto de ser que adotou Flaubert diante do problema do Ser, ou seja, seríamos capazes de decifrar a ambição do jovem escritor como significante e como uma das modalidades de ser fundamentais de Flaubert; aliás, "é por esta razão que a irredutibilidade do resultado obtido desvelar-se-á com evidência; não por que seja o mais pobre e abstrato, mas por ser o mais rico: a intuição, aqui, será apreensão de uma plenitude individual" (SARTRE, 2010, p. 608).

Caso estejamos de acordo com o fato de que a pessoa é uma totalidade (isto é, uma consciência de si e consciência do mundo, um pro-jeto que se transcende em direção a seus possíveis), seria de um grande equívoco tentar recompô-la através de uma adição ou de uma organização de diversas tendências que descobrimos empiricamente nela: ao contrário disso, é preciso considerar que cada inclinação, cada tendência, cada gesto (por mais banal que seja) revela e exprime a pessoa inteira, "como a substância espinozista se exprime inteira em cada um de seus atributos. Sendo assim, devemos descobrir em cada tendência, em cada conduta do sujeito, uma significação que a transcende" (SARTRE, 2010, p. 609); trata-se, portanto, de visar a pessoa como totalidade sintética. Por conseguinte, diremos que a psicanálise existencial possui como orientação fundamental a interpretação de tal ou tal individualidade concreta como totalidade significante. N'outras palavras, cada atitude empiricamente observável é, por si mesma, a expressão da "escolha de um caráter inteligível", ou seja, cada atitude empírica, por mais banal que seja ela, significa e remete ao projeto de ser do para-si, projeto de ser revestido por uma escolha original de seu ser: "se a atitude empírica significa a escolha do caráter inteligível, é porque ela é em si mesma essa escolha" (SARTRE, 2010, p. 609). Se cada atitude empírica significa a "escolha de um caráter inteligível" isso significa, sublinhemos, que cada atitude empírica remete, exprime a escolha original que o para-si faz de seu ser: se, por exemplo, remo neste rio, eu não sou senão esse pro-jeto concreto de remar, mas como esta atitude empiricamente observável exprime a totalidade de meu ser, este pro-jeto concreto significa a escolha de mim mesmo como totalidade nessas circunstâncias, significa meu projeto fundamental de mim mesmo nessas circunstâncias particulares; portanto, o método especial que visa revelar a significação fundamental que o projeto comporta deve, sobretudo, operar uma "comparação entre as diversas tendências empíricas de um sujeito" para, então "tentar descobrir e destacar o projeto fundamental comum a todas - e não por uma simples soma ou recomposição dessas tendências, (pois) em cada uma delas acha-se a pessoa em sua inteireza" (SARTRE, 2010, p. 609). Sendo assim, apenas nos daremos por satisfeitos quando, finalmente, alcançarmos esta irredutibilidade evidente que é o projeto original/fundamental ${ }^{11}$ e o fim projetado enquanto o ser mesmo do para-si considerado.

${ }^{11}$ Ressaltemos, novamente, que "esse projeto fundamental não deve remeter, com efeito, a nenhum outro e deve ser concebido por si”" (SARTRE, 2010a, p. 610). 
O projeto original/fundamental, de acordo com Sartre, visa o ser do para-si enquanto ser-no-mundo que transcende a si mesmo e o mundo rumo aos possíveis que lhe sãos próprios; destarte, o projeto de ser ou desejo de ser não pode provir de uma diferenciação fisiológica ou de uma contingência empírica, pois não se distingue, como frisamos, do ser do para-si: "o para-si, com efeito, é um ser no qual o ser está em questão em seu ser sobre a forma de projeto de ser" e ser, para o para-si, "é fazerse anunciar o que se é por um possível sob o signo de um valor" (SARTRE, 2010, p. 610); possível \& valor, portanto, pertencem ao ser do para-si enquanto projeto de ser galvanizado por um desejo de ser. O para-si é, ontológicamente, uma falta de ser que visa, através de seus possíveis (sendo o possível aquilo que lhe falta), o valor que assombra o para-si como totalidade ser faltado: doravante, "é a mesma coisa dizer que o valor e o possível existem como limites internos de uma falta de ser que não poderia existir senão enquanto falta de ser - ou que a liberdade, surgindo, determina seu possível e, através disso, circunscreve seu valor" (SARTRE, 2010, p. 610). E se o projeto original reúne, por conseguinte, a escolha originária do para-si enquanto esta escolha é escolha de si como tentativa, via desejo, de realização da Totalidade-Valor através de possíveis, é preciso convir que, uma vez atingido este projeto original irredutível evidente -, não podemos ir adiante dele na medida em que ele é pari passu projeto de ser: "não podemos, evidentemente, remontar mais além do ser, e entre projeto de ser, possível e valor e, de outro lado, o ser, não há nenhuma diferença" (SARTRE, 2010, p. 610). Ora, se o homem é, nos dizeres do próprio Autor, fundamentalmente desejo de ser, a existência desse desejo não poderia ser jamais estabelecida por uma indução empírica, pois ele diz respeito, antes, a uma descrição $a$ priori do ser do para-si, o que equivale a dizer que ele é de ordem ontofenomenológica, isto é, este desejo de ser é constitutivo do ser do para-si enquanto falta de ser que é a si mesmo sua própria falta de ser como tentativa constante de preenchimento dessa falta.

No mais, se cada conduta empírica revela a totalidade de ser do para-si como desejo de ser ou valor, isso é devido ao fato de que o projeto original (projeto de ser) exprime-se em cada uma dessas tendências empiricamente observáveis; nesta toada, não devemos separar, como fez Plantão a despeito do sensível e do inteligível, as tendências empíricas (nível ôntico) do projeto de ser (nível ontológico), pois essas tendências, em si mesmas, são a expressão do projeto original de ser: "cada tendência empírica existe com o projeto de ser em uma relação de expressão e de satisfação simbólica", o que não significa, por outro lado que "o desejo de ser primeiro seja para só depois expressar-se pelos desejos a posteriori; mas sim que ele não é nada fora da expressão simbólica que encontra nos desejos concretos" (SARTRE, 2010, p. 611). Em outras palavras, e como imperativo de uma filosofia do concreto, não se trata de pensar, incialmente, a existência de um desejo de ser (nível ontológico) para, em seguida, pensar os mil sentimentos particulares e empíricos (nível ôntico); bem ao contrário, o desejo de ser não se manifesta senão em cada sentimento empírico como manifestação deste para-si singular: o nível ôntico e o nível ontológico operam em uma relação fundamental e deste "duplo ôntico-ontológico", depreendemos a importância teórica de se levar em consideração cada gesto do homem, na medida em que este gesto é expressão de seu projeto de ser enquanto desejo de ser que visa a 
realização da totalidade em-si-para-si ${ }^{12}$. Este ideal - o em-si-para-si -, como bem sabemos, não representa senão o ideal/projeto da realidade-humana de ser Deus, isto é, um para-si que continue sendo consciência, mas, ao mesmo tempo, seja fundamento de seu próprio ser.

Para o filósofo, ainda que o sentido (ontológico) do desejo seja, em última instância, o projeto de ser Deus, "o desejo não é jamais constituído por esse sentido, mas, ao contrário, representa sempre uma invenção particular de seus fins" (SARTRE, 2010, p. 612); fins que, como salienta Sartre, são perseguidos a partir de uma situação empírica particular: nesta toada, o desejo de ser se realiza como desejo de maneira de ser, e este desejo de maneira de ser, por sua vez, exprime-se como o sentido das miríades dos desejos concretos que constituem nossa vida consciente. Desta arquitetura simbólica do desejo, somos capazes de desvelar, ao menos, três graus que constituem esta referida arquitetura: o desejo empírico (ôntico) através do qual discernimos uma simbolização de um desejo fundamental e concreto que é a pessoa e que representa a maneira pela qual ela decidiu que o ser estaria em questão em seu ser, o desejo fundamental que exprime concretamente e no mundo, através da situação singular que envolve a pessoa, a estrutura abstrata e significante do desejo de ser enquanto estrutura universal (quer dizer, presente em todos os para-si) que faz deste para-si singular uma realidade-humana ${ }^{13}$ pela qual ele constitui sua comunidade com o outro (aliás, é esta estrutura ontológicamente universal que possibilita afirmar que existe uma verdade do homem e não apenas individualidades incomparáveis). Ora, se o desejo de ser, em sua pureza abstrata, é a verdade ontológica do desejo concreto e fundamental, isso não significa afirmar que ele exista a título de realidade ou como objeto de uma tese (objeto da consciência reflexiva), pois é esse desejo fundamental, a partir da situação concreta e individual da pessoa e da miríade de seus desejos empíricos enquanto simbolização deste desejo concreto, que fará com que ela crie seus fins particulares para tentar realizar o Valor: "a concretude absoluta e a completude, a existência como totalidade, pertencem, portanto, ao desejo livre e fundamental ou pessoa" (SARTRE, 2010, p. 612). Em outros termos, o desejo de ser representa, como estrutura ontológica universal e fim último da realidade-humana, um desejo de ser Deus, mas este desejo não pode ser enquadrado como uma natureza humana, como uma essência ou como um entrave à liberdade, pois é este para-si singular (ser-no-mundo), galvanizado por seu projeto original (que é projeto de ser), que escolherá (via escolha original) o modo pelo qual ele tentará solucionar o problema do Ser; e esta escolha, por seu turno, será expressa como desejo concreto e fundamental - modalizando a hierarquia dos possíveis -, e no qual os desejos empíricos não são senão uma simbolização: daí a afirmação de que "a psicanálise existencial possui por objetivo encontrar, através desses projetos empíricos e concretos, a maneira original que cada um tem de escolher seu ser" (SARTRE, 2010, p. 645). Ainda que o objetivo último (objetivo ontológico) da realidade-humana seja o desejo de ser Deus (em-si-para-si), o que importa, finalmente, é a livre maneira como cada para-si perseguirá (até o fim de sua vida)

\footnotetext{
12 "O ser que figura como objeto do desejo do para-si é, portanto, um em-si que seria a si mesmo seu próprio fundamento (...)" (SARTRE, 2010a, p. 611).

${ }^{13} \mathrm{O}$ desejo de ser, enquanto estrutural geral da realidade-humana, representa a realidade-humana na pessoa, isto é, neste para-si singular.
} 
este fim, ou seja, é esta livre maneira (livre porque escolhida livremente por ele) de perseguir este fim que fará com que o para-si, ainda que imbuído na realidadehumana qualquer, seja um ser-no-mundo individual significando o mundo através de uma transcendência pessoal. Finalmente, diremos que o desejo de ser é a estrutura ontológica da realidade-humana qualquer e que o desejo fundamental e concreto, por seu turno, é a estrutura do para-si como ser-no-mundo, isto é, como pessoa singular e individual: "depois dessas observações, podemos compreender que a estrutura abstrata e ontológica 'desejo de ser', se bem que represente a estrutura fundamental e humana da pessoa, não poderia ser um entrave à sua liberdade" (SARTRE, 2010, p. 613).

Além disso, a liberdade, definida ontofenomenológicamente, é precisamente o ser que se faz falta de ser, e se o desejo é idêntico a esta falta de ser, temos de concluir que a liberdade apenas pode surgir como ser que se faz desejo de ser, ou seja, como pro-jeto do para-si em ser em-si-para-si: "alcançamos aqui uma estrutura abstrata que não poderia ser considerada de nenhuma maneira como a natureza ou a essência da liberdade, pois a liberdade é existência e a existência, na liberdade, precede a essência", afinal, continua o filósofo, "a liberdade é surgimento imediatamente concreto e não se distingue de sua escolha, isto é, da pessoa" (SARTRE, 2010, p. 613). Se a liberdade, em regime de realidade-humana qualquer, é falta de ser que se faz desejo de ser Deus, tal consideração não remete senão à verdade da liberdade enquanto significação humana (logo, universal) dessa liberdade: neste nível das estruturas gerais do para-si, nível da verdade humana da pessoa realidade-humana qualquer -, a fenomenologia ontológica apresentou-se como um instrumento teórico fundamental (afinal, não foi senão este instrumento que viemos utilizando até aqui), mas as investigações não poderiam encontrar aí seu termo final, uma vez que o para-si, além de ser realidade-humana, é um ser-no-mundo particular, quer dizer, uma transcendência singular. Portanto, para o estabelecimento e a classificação dos desejos fundamentais ou pessoas, um método especial é requerido, pois este método deve visar, para além das estruturas universais da realidadehumana (ontológica fenomenológica) e da nomenclatura dos desejos empíricos (psicologia), a singularidade do ato livre: não se trata mais aqui do homem em geral, mas de uma tipologia das pessoas. Se

[...] pertence a uma realidade-humana em geral o fato de podermos submeter um homem qualquer a essa investigação (...), em si mesma, essa investigação, bem como seus resultados, estão, por princípio, totalmente fora das possibilidades de uma ontologia. Por outro lado, a pura e simples descrição empírica somente pode fornecer-nos nomenclaturas e colocar-nos frente a pseudo-irredutíveis (desejo de escrever ou de nadar, amor ao perigo, ciúme, etc.). Com efeito, não convém catalogar a lista das condutas, tendências e inclinações, mas é preciso, ainda, decifrá-las, ou seja, é preciso saber interrogá-las. Tal investigação só pode ser levada a cabo segundo as regras de um método específico. É este método que denominamos psicanálise existencial (SARTRE, 2010, p. 614).

Método específico de decifração e interrogação das condutas individuais do para-si, a psicanálise existencial parte do princípio de que o homem é uma totalidade e não uma coleção; ora, isso significa, como não nos furtamos de aludir, que cada 
homem exprime-se inteiro na mais insignificante e superficial de suas tendências: para o Autor, não há um único gosto, gesto ou tique que não revele o homem em sua totalidade. Se coube à ontologia fenomenológica a tarefa de evidenciar o movimento de unificação, de totalização e de destotalização perpétuo que realiza o ser-para-si, caberá à psicanálise existencial, enquanto método que opera no campo da singularidade, interpretar as diferentes modalidades de unificação, isto é, interpretar como cada para-si singular responde à sua situação; à psicanálise existencial é dada a tarefa de clarificar a singularidade própria de tal ou tal existência vivida. $\mathrm{O}$ objetivo desta psicanálise, mais ou menos evidenciado aqui, será o de decifrar os comportamentos empíricos do homem, clarificar, ao máximo (até que se chegue ao projeto original), as revelações que cada indivíduo contém e, então, fixá-las conceitualmente. Ora, se seu ponto de partida é a experiência, seu ponto de apoio é a compreensão pré-ontológica e fundamental que o homem possui da pessoa humana, pois embora muitos negligenciem as indicações conditas em um gesto, palavra ou expressão significante, "cada pessoa humana não deixa de possuir a priori o sentido do valor revelador dessas manifestações, nem de ser capaz de decifrá-las (...) se bem auxiliada e conduzida pela mão" (SARTRE, 2010, p. 614). Tendo como horizonte o pressuposto de que o sujeito possui a priori esta compreensão pré-ontológica, o trabalho essencial desse método será uma hermenêutica, logo, uma decifração, uma conceptualização e uma determinação: "a psicanálise existencial propõe-se, assim, como isso que deverá, ao mesmo tempo, seguir e guiar o 'movimento' espontâneo da compreensão" (BOURGAULT, 2002, p. 47). Por conseguinte, seu método será comparativo na medida em que cada conduta humana simboliza, à sua maneira, a escolha fundamental e, ao mesmo tempo, cada uma delas mascara essa escolha a partir de sua oportunidade histórica e de seus caracteres ocasionais; nesta toada, será "pela comparação entre tais condutas que faremos jorrar a revelação única que todas elas exprimem de maneira diferente" (SARTRE, 2010, p. 614); e o esboço primeiro deste método foi-nos dado por Freud e seus discípulos.

Doravante, a partir desta última observação, convêm fazer o inventário teórico das possíveis semelhanças e diferenças entre a psicanálise existencial e a psicanálise tradicional freudiana (chamada por Sartre, igualmente, de psicanálise empírica); comecemos, então, pelas semelhanças: I) da mesma maneira que a psicanálise freudiana, a psicanálise existencial considera que as manifestações da vida psíquica revelam e, ao mesmo tempo mascaram, estruturas globais e fundamentais que constituem propriamente a pessoa, logo, tudo é significante; II) assim como a psicanálise empírica assevera que a afetividade primeira do indivíduo é, antes de sua história, uma cera virgem, a psicanálise sartreana nada reconhece antes do surgimento da liberdade humana, o que significa que ela não considerará que existam dados primeiros, quer dizer, inclinações hereditárias, caráter, etc.; em suma, o psiquismo não pode ser decomposto em dados primeiros: ambas as psicanálises "consideram o ser humano como uma historização perpétua e procuram descobrir, mais do que dados estáticos e constantes, o sentido, a orientação e os avatares desta história" (SARTRE, 2010, p. 615), en résumé, ambas as psicanalises lidam com uma hermenêutica das condutas humanas, fundada na afirmação do caráter significativo de todo fenômeno humano; III) neste horizonte teórico, tanto uma como outa consideram somente o homem no mundo, isto é, em situação; daí que 
a investigação psicanalítica, porque tenta restituir a vida do sujeito em situação (desde seu nascimento, portanto), utilizará o máximo de documentos objetivos acerca da história deste sujeito para restituir então, não um puro evento psíquico, mas uma díade: "o evento crucial da infância e a cristalização psíquica entorno deste evento. Aqui, ainda trata-se de uma situação" (SARTRE, 2010, p. 615); finalmente, cada fato histórico deverá ser considerado duplamente, isto é, enquanto fato da evolução psíquica e como símbolo dessa evolução; IV) ambas as psicanálises buscam, doravante, desvelar a atitude fundamental do indivíduo em situação; contudo, se a psicanálise empírica busca determinar o complexo, a psicanálise existencial visa, como já sabemos, determinar o projeto de ser e a escolhe original, escolha que é operada "frente ao mundo e, sendo escolha da posição no mundo, é totalitária como o complexo" (SARTRE, 2010, p. 615), é escolha da atitude do para-si em relação a si mesmo e ao mundo: "a escolha original conglomera em uma síntese pré-ontológica a totalidade do existente e, como tal, é o centro de referências de uma infinidade de significações polivalentes" (SARTRE, 2010, p. 615); é o segredo e termo último da investigação psicanalítica sartreana; V) ambos os métodos consideram que o sujeito, enquanto analisando, não se encontra em posição privilegiada para proceder a essas investigações pré-ontológicas sobre si mesmo: na medida em que para a psicanálise empírica o sujeito não pode levar a cabo uma investigação sobre si mesmo, pois, por princípio, não possui acesso ao seu inconsciente, para a psicanálise de Sartre, ao contrário, o sujeito não está em posição privilegiada para conduzir uma auto investigação acerca de si porque, do ponto de vista ontofenomenológico, o para-si não pode objetivar-se, dado o caráter fugidio da díade pré-reflexiva da consciência (reflexo-refletidor). Todavia, a psicanálise existencial vislumbra - ao contrário da freudiana - uma possível possibilidade de autoanálise se, e somente se, o sujeito (e Sartre não diz exatamente como) renunciar a todo e qualquer benefício de sua posição particular; renúncia que o faria interrogar-se a si mesmo como se ele fosse um outro. Ora, uma tal possibilidade, aliás, marca (ainda que estejamos, neste momento, inventariando as semelhanças entre ambos os métodos) a diferença teórica que separará inexoravelmente ambas as psicanálises, qual seja: só há esta possibilidade de uma autoanálise, pois a psicanálise existencial rechaça, sem que haja nenhuma possibilidade de acordo, o primado do inconsciente freudiano; se o complexo difere do projeto original, isso se deve, sobretudo, ao fato de que Freud concebe o complexo como inconsciente e submetido às leis da natureza. Já para o filósofo, "o fato psíquico é (...) coextensivo à consciência" (SARTRE, 2010, p. 616), destarte, o projeto fundamental é plenamente vivido e totalmente consciente ao sujeito, o que não significa, por outro lado, que este projeto seja conhecido por ele. Explicitado, ligeiramente, os mecanismos desta psicanálise, voltemos à biografia sobre Baudelaire.

III

Ao perder o pai com seis anos de idade, Baudelaire "vivia na adoração de sua mãe; fascinado, cercado de olhares e de cuidados, ele ainda não sabia que existia como uma pessoa, mas se sentia unido ao corpo e ao coração de sua mãe por um tipo de participação primitiva e mística" (SARTRE, 2012, p. 18). Para o filósofo, esta 
"união/participação primitiva e mística" à sua mãe, faz com que ela apareça ao pequeno órfão de pai como um ídolo e, ao mesmo tempo, faz com que ele se apreenda a si mesmo como "consagrado pela afeição que ela lhe dirige", e, assim, "longe de sentir-se uma existência errante, vaga e supérflua, ele pensa a si mesmo como filho de direito divino. Ele está sempre vivo nela (...)" (SARTRE, 2012, p. 18). Absorvido inteiramente nesta divindade-mãe cuja existência, aos seus olhos, é necessária e de direito, o menino sente-se justificado. E ele poderia ter levado esta infância feliz e justificada não fosse, para seu infortúnio, o novo casamento da mãe-ídolo; a este casamento, segue-se, também, a saída de Baudelaire de sua casa rumo a uma pensão/colégio interno: é a partir deste trágico evento que podemos localizar sua famosa "fenda": desvencilhando-se repentinamente da mãe-doação-desentido/existência, o jovem é bruscamente lançado, sem transição alguma, na existência pessoal; separado de sua mãe, "ele perdeu suas justificativas, ele descobre na vergonha que ele é uno, que sua existência lhe é dada por nada" (SARTRE, 2012, p. 19). É salutar fazer notar que esta "separação ontológica" é crucial no vir a ser de Baudelaire: na medida em que sua mãe representava o núcleo último de doação de sentido e justificação de seu ser, ao vê-la casar-se novamente e separar-se dele, isso faz irromper nele um sentimento de declínio, isolamento e abandono existencial pensados, sobretudo, como um destino: "sentimento de solidão, desde minha infância. Apesar da família - e no meio dos camaradas, sobretudo - sentimento de destino eternamente solitário" (BAUDELAIRE apud SARTRE, 2012, p. 19). E se ele pensa este abandono tramado pelo destino, isso significa que ele não o sofre passivamente e não deseja que ele seja temporário: apreendendo-se a si mesmo como destinado ao abandono e isolamento, "ele se fecha nisso e, porque o condenaram a isso, ele quer, ao menos, que a condenação seja definitiva"; e é aqui, precisamente, que tocamos a escolha original que Baudelaire fez de si próprio, "este engajamento absoluto pelo qual cada um de nós decide, em uma situação particular, o que será e o que é" (SARTRE, 2012, p. 19). De acordo com a interpretação sartreana, o poeta decide retomar por si próprio este isolamento/abandono ontológico, ele decide reivindicá-lo para si, isto é, decidi vivê-lo de maneira não passiva; o filósofo novamente: "Ele provou que ele era um outro, pelo brusco desvelamento de sua existência individual, mas, ao mesmo tempo, ele afirmou e retomou por si mesmo esta alteridade, na humilhação, no rancor e no orgulho" (SARTRE, 2012, p. 20).

Contudo, esta experiência da alteridade não é senão o sentimento de uma alteridade formal: ainda que Baudelaire reivindique esta experiência (advir outro em relação à mãe e seu entorno), ela, paradoxalmente, não poderia fazer com que ele se distinguisse de outrem, pois esta irrupção de si ou "aparição fortuita e perturbadora da consciência de si" é advinda a ele a partir de seu abandono ontológico; "a criança que encontrou a si mesma no desespero, no furor e no ciúmes, focará sua vida na meditação estagnada de sua singularidade formal" (SARTRE, 2012, pp. 21-22). Se o aparecimento da consciência de si, na maior parte das crianças, é uma "intuição fulgurante" e "perfeitamente vazia", e faz com que elas adquiram a convicção de que são outros que os outros e cada um dos outros é, paralelamente, outro, o mesmo já não pode ser dito da criança Baudelaire para quem a consciência de si é atravessada pelo doloroso sentimento do abandono/isolamento/solidão: "Eu sou um outro. Um outro de todos vocês que me fizeram sofrer. Vocês podem me perseguir em minha 
carne, mas não em minha 'alteridade'..." (BAUDELAIRE apud SARTRE, p. 22). Afirmando sua alteridade formal e tomando-a para si, Baudelaire está constantemente em presença de sua consciência de si, consciência guiada por um orgulho metafísico; todavia, este orgulho é tão infeliz quanto puro, pois "gira em falso e nutre-se de si mesmo (...), repousa sobre nada, é vago porque a diferença que o funda é uma forma vazia e universal" (SARTRE, 2012, pp. 22-23).

Em outras palavras, este orgulho não afirma senão esta alteridade formal que aparece a ele como símbolo de uma singularidade profunda: constantemente debruçado sobre si, assim como Narciso encontra-se debruçado sobre as águas que lhe fornecem sua imagem, "Baudelaire é o homem que jamais se esquece de si. Ele olha a si mesmo vendo, ele olha para se ver vendo", logo, "é sua consciência da árvore, da casa, que ele contempla e as coisas não aparecem a ele senão através dela, mais pálidas, mais pequenas, menos tocantes, como se ele as percebesse através de um binóculo" (SARTRE, 2012, p. 23); isso significa que as coisas - objetos transcendentes -, antes de se apresentarem como complexo de utensílios, têm a única missão de remeterem à consciência de si, elas jamais valem por si mesmas uma vez que "sua única missão é a de fornecer a ele - Baudelaire - a ocasião de se contemplar na medida em que ele as vê" (SARTRE, 2012, p. 24) ${ }^{14}$. Ora, se as coisas se lhe apresentam unicamente como oportunidade para se ver vendo, é preciso sublinhar que há entre o poeta e o mundo uma distância original intransponível: é desta distância - fatura constante desta contemplação de si mesmo - que emerge sua famosa lucidez, marca de sua singularidade profunda. Todavia, como nota Sartre, tal lucidez/singularidade não passa senão de um esforço de recuperação de si: se sua singularidade vale para nós que a apreendemos de fora, para o poeta, que se considera de dentro, ela lhe escapa inteiramente: "ele buscava sua natureza, isto é, seu caráter e seu ser, mas ele somente assistia a um longo desfile monótono de seus estados" (SARTRE, 2012, p. 25); sua singularidade, enquanto consciência tética de si, é incapaz de apreender-se a si mesma, pois, se bem nos lembramos, o vivido não é passível de conhecimento. Assim, Baudelaire busca apreender-se em vão e, por mais pleno de si mesmo que ele possa estar, esse "si mesmo não passa de um humor brando e vítreo, privado de consistência, de resistência, que ele não pode nem julgar e nem observar" (SARTRE, 2012, p. 25). Eis apresentado aqui o "drama" de Baudelaire: sua grande clareza reflexiva não é capaz de apreender o "processo dialético da vida psíquica", ou seja, o vivido; e se ele se esforça para ver a si mesmo enquanto vê, este esforço é vão porque "para ver-se, seria necessário ser dois. Baudelaire vê suas mãos e seus braços porque o olho é distinto da mão; mas o olho não pode ver-se a si mesmo" (SARTRE, 2012, p. 26). Dessa maneira, por mais que o poeta monte guarda constante sobre si, ele jamais seria capaz de apreender seu corpo-para-si (uma vez que esta dimensão da corporeidade é da ordem do existido), e muito menos sua alteridade, pois esta é buscada a partir do olhar do outro; "ele vê ou busca ver a si mesmo como se ele fosse outro" (SARTRE, 2012, p. 79). Mas vejamos, contudo, que este esforço baudelairiano de apreensão de si é levado ao seu extremo, o

14 É nesse sentido que Sartre afirma que a arte de Baudelaire visa apresentar as coisas, não em si mesmas, mas através de uma "espessura de consciência humana": "O que é a arte pura de acordo com a concepção moderna? É criar uma magia sugestiva contendo, ao mesmo tempo, o objeto e o sujeito, o mundo exterior ao artista e artista ele mesmo" (BAUDELAIRE apud SARTRE, 2012, p. 24). 
que significa que ele manterá esta dualidade que é a consciência reflexiva: sua lucidez desdobra-se em esforço para ser dois na tentativa de realizar, através disso, a possessão final do "Eu pelo Eu": "Ele exaspera, portanto, sua lucidez: ele não era senão sua própria testemunha, ele tentará se tornar seu próprio carrasco: o Heautontimoroumenos ${ }^{15}$. Pois a tortura faz nascer uma díade estritamente unida na qual o carrasco se apropria da vítima" (SARTRE, 2012, p. 27).

Se Baudelaire visa ser, ao mesmo tempo, "a vítima e o carrasco", isso significa, ontofenomenológicamente, que ele busca dividir o que, todavia, não pode ser dividido: a consciência reflexiva e a consciência refletida. Ora, a consciência reflexiva e consciência refletida estão separadas de direito, mas unidas de fato, pois "de uma certa maneira, elas não são senão uma" (SARTRE, 2012, p. 27). Sobremaneira, se o poeta visa opô-las como dois seres distintos, isso sinaliza este esforço em ser dois: operando por meio de uma reflexão impura por meio do qual o refletido é apreendido como em-si, Baudelaire "fingirá uma espontaneidade desconcertante, ele aparentará abandonar-se aos impulsos os mais gratuitos para, repentinamente, elevar-se diante de seu próprio olhar como um objeto opaco e previsível, em suma, como um Outro que ele" (SARTRE, 2012, p. 27). Contudo, como a consciência reflexiva e a consciência refletida, de uma certa maneira, não são senão uma, ele jamais logrará êxito em surpreender-se a si mesmo como Outro que ele: é desta constante tentativa (fracassada) de cissiparidade entre consciência reflexiva \& consciência refletida que diremos, à guisa de Sartre, que Baudelaire é o homem que escolheu ver-se como se ele fosse um outro. Todavia, como afirma o filósofo, o poeta sabe que ele jamais alcançará uma verdadeira possessão de si mesmo, mas apenas esta "languida degustação" que caracteriza o conhecimento reflexivo; advém daí seu tédio, isto é, a incapacidade de surpreender-se como outro, a impossibilidade de operar a dualidade da consciência reflexiva e refletida, o fracasso de fazer com que o refletido seja em-si. E se ele esta ciente desta impossibilidade, podemos dizer, igualmente, que ele é o homem que provou o sabor de sua existência, quer dizer, que vislumbrou, a partir da intuição de sua singularidade formal, sua inteira gratuidade injustificável, e advém deste fato, portanto, a intuição profunda de sua inutilidade: "se, de início, degustou-se até à náusea esta consciência sem rima e nem razão, que deve inventar as leis às quais ela quer obedecer, a utilidade perde toda significação; a vida não é mais do que um jogo, o homem deve escolher por si mesmo seu objetivo" (SARTRE, 2012, p. 30). Sua lucidez, enquanto esforço para recuperar-se a si mesmo e ser dois, não é senão esta constante operação reflexiva que visa a dualidade da consciência reflexiva e intui, através da alteridade formal, a gratuidade injustificável da existência: é nesse sentido que seu orgulho, sua lucidez, seu tédio e sua preguiça não passam de uma única e mesma coisa, isto é, são o resultado de uma "intuição metafísica que o homem normal aplica-se a mascarar", pois Baudelaire é o homem que descobre, quando da trágica separação de sua mãe, a "solidão infinita desta consciência 'vasta como o mar' e que é, ao mesmo tempo, a consciência e sua consciência" (SARTRE, 2012, p. 31). E se ele descobre, através desta "intuição metafísica", a gratuidade injustificável da transcendência, esta

15 Trata-se de um poema de Baudelaire cujo verso "eu sou a ferida e a faca/ e a vítima e o carrasco" (BAUDELAIRE apud SARTRE, 2012, p. 27) é usado por Sartre para demonstrar este esforço de dualidade da consciência reflexiva. 
descoberta é, ipsis litteris, revelação da liberdade humana, isto é, revelação de que ele, Baudelaire, não pode encontrar, em si e nem fora de si, nenhum recurso contra a sua liberdade: ele está condenado a justificar, sozinho, sua existência; e por mais que busque a si mesmo, ele somente encontra a condição humana, quer dizer, esta injustificável existência livre: "ele é o homem que, provando mais profundamente sua condição de homem, mais apaixonadamente buscou mascará-la". (SARTRE, 2012, p. 41).

Por ter escolhido a lucidez ${ }^{16}$ e por ter descoberto, apesar de si, a gratuidade da existência e, consequentemente, a temível liberdade da consciência, Baudelaire experiência seu ser-para-si ao mesmo tempo em que busca, todavia, mascará-lo: para ele "o que é criado pelo espírito é mais vivo do que a matéria" (BAUDELAIRE apud SARTRE, 2012, p. 41), ou seja, a consciência advém como produtora de significação e criação ex nihilo contínua, logo, é pela criação que ele irá definir o homem e não pela ação, pois pelas lentes baudelairianas, a criação é pura liberdade, quer dizer, pura criação de valores. Contudo, o filósofo atenta para o fato de que, percorrendo o corpus baudelairiano, deparamo-nos, não com uma "ousadia nietzschiana na busca do Bem e do Mal", mas, bem ao contrário, com uma noção moral recebida através dos outros e jamais contestada por ele: ele adota, sem resistência/contestação, a moral de seu padrasto, o general Aupick. Sobremaneira, todos esses princípios morais advindos da educação cristã e burguesa, sob sua pena, são transvestidos negativamente; sobriedade, castidade, caridade, trabalho não são usados em sentido positivo, isto é, não traçam uma linha de conduta e não permitem resolver os problemas das relações com o outro ou para consigo mesmo, mas "representam, todos, simplesmente uma série de defesas rigorosas e estritamente negativas" (SARTRE, 2012, p. 45). O paradoxo desta atitude de manutenção dos conceitos cristão, conceitos galvanizados por uma negatividade, advém precisamente do fato de que o poeta os utiliza contra si ${ }^{17}$ : ora, mas por que este poeta que intuiu a consciência como única fonte válida para a criação/significação dos valores, decide manter e afirmar as normas e moralidade que, justamente, o tornam culpado perante todos? Para Sartre, esta atitude é, como havíamos mencionado acima, um recurso contra esta liberdade criadora que lhe causa medo: "a grande liberdade criadora dos valores emerge no nada: ela lhe causa medo. A contingência, a injustificabilidade, a gratuidade assediam sem descanso aquele que tenta fazer surgir no mundo uma realidade nova" (SARTRE, 2012, p. 49). Destarte, o poeta não pretende afirmar sua singularidade nesta "realidade nova", mas, bem ao contrário, ele a afirma em um mundo estabelecido; ele a afirma contra sua família e inquisidores, o que não significa, por outro lado, que ele seja um revolucionário, pois se trata, sobretudo, de uma revolta; logo, ele não pretende destruir e muito menos ultrapassar as normas, mas apenas posicionar-se contra elas, quer dizer, afirmá-las para, ao mesmo tempo,

16 No decorrer desta biografia existencial, Sartre mostrará que esta lucidez é, sobretudo, autopunitiva: afirmando, explicitamente, a moral de seus juízes, Baudelaire, numa espécie de "jogo sádico", esforça-se, também de maneira explicita, em contrariá-la; "(...) ele visa uma culpa livremente constituída como culpa em referência às normas já estabelecidas" (SARTRE, 2012, p. 79).

17 Ver, por exemplo, o episódio no qual o conteúdo de um de seus livros recebe acusações: ao invés de defender-se contra elas, Baudelaire afirma aceitar a moral que o ataca é nesse sentido que podemos afirmar que "ele tomou o partido de seus carrascos, de Ancelle, de Aupick, dos policiais do Império, dos acadêmicos; ele afirmou o chicote deles, ele pediu que fosse constrangido pelo terror de praticar as virtudes que eles defendem (...)" (SARTRE, 2012, p. 47). 
culpar-se: "os direitos que ele contesta com força, ele os conserva no mais profundo de seu coração; se eles desaparecessem, sua razão de ser e sua justificação desapareceriam com eles" (SARTRE, 2012, p. 50).

É deste quiprocó descrito acima que o filósofo poderá afirmar, finalmente, que Baudelaire jamais tenha sonhado em destruir o conceito tradicional de família, pois ele nunca teria ultrapassado o estado da infância; desta assertiva, segue-se, os princípios do, digamos, "diagnóstico" de Baudelaire: ele é aquele que decide ver-se como se fosse Outro. Para que expliquemos esta escolha original de si do poeta, fazse necessário que, assim como Sartre, pensemos a relação da criança aos pais ${ }^{18}$. Para ele, a criança considera os pais como Deuses, seus atos e julgamentos são absolutos, "eles incarnam a Razão universal, a lei, o sentido e o objetivo do mundo", e "quando esses seres divinos põem seu olhar sobre ela (a criança), esse olhar a justifica sobretudo até o coração mesmo de sua existência; ele a confere um caráter definido e sagrado: porque eles não podem se enganar, ela é como eles a veem" (SARTRE, 2012 , p. 50). Ora, n’outras palavras, poder-se-ia afirmar que a criança é, sobretudo, um objeto, quer dizer, ela não possui (ainda) possibilidades próprias, tudo o que ela vê e sente é mediado pelo olhar onipresente dos pais-deuses; e se, como afirma o poeta, a criança vê tudo como novidade, esta novidade, para ela, já foi vista, classificada e nomeada pelos outros: "cada objeto se lhe apresenta com uma etiqueta; ele é eminentemente tranquilizador e sagrado porque o olhar dos adultos paira ainda por cima" (SARTRE, 2012, p. 51); isso significa que a criança não explora regiões desconhecidas, mas apenas regiões já marcadas e significadas pelo olhar-deus dos adultos. Se os pais, enquanto detentores e suporte da razão de ser da criança, detém este olhar de justificação da existência, é precisamente este olhar, esta segurança absoluta, que Baudelaire lamente, como já havíamos entrevisto, ter perdido: saindo do escopo do olhar-justificador da mãe, ele experiencia sua própria transcendência (processo de individuação ${ }^{19}$ ) e perde, eo ipso, sua essência e sua verdade: "injustificado, injustificável, ele realiza, bruscamente, a experiência de sua terrível liberdade (...), ele emerge repentinamente na solidão e no nada. E é isso que Baudelaire não quer de maneira alguma" (SARTRE, 2012, p. 52). Para o filósofo francês pouco importa atribuir ao poeta, quando de sua recusa da passagem da criança-objeto-sem-possibilidades-próprias ao homem-detentor-de-suas-própriaspossibilidade, um complexo de Édipo mal liquidado (isto significa que pouco importa que ele tenha ou não tenha desejado sexualmente a mãe), o que importa realmente e isso a partir das elucubrações teóricas do ser-para-si-para-outro - é que ele recusou liquidar o "complexo teológico que assimila os pais às divindades" (SARTRE, 2012, p. 53). Entrementes, isso não significa que os pais, sobretudo a mãe, seja, para ele,

\footnotetext{
18 Não nos furtemos de indicar que, paulatinamente, Sartre "reabilita" a infância para a plena compreensão acerca de determinado homem. Nesse sentido, ver-se-á, por exemplo, em L'Idiot de la famille, o cuidado sartreano em restituir o que ele chama de proto-história de Flaubert, pois "de uma certa maneira, se toda pessoa singular possui, por ela mesma, a estrutura do signo e se o conjunto totalizado de seus possíveis e de seus projetos lhe é dado como seu sentido, o núcleo duro desse sentido é a infância", logo, "sem a infância, é pouco dizer que o biógrafo constrói sob a areia: ele constrói sob a bruma com nevoeiro" (SARTRE, 1971, pp. 54-55).

${ }^{19}$ Este processo de individuação, como nota Coorebyter (2000, p. 232), está no princípio da análise sartreana da relação do para-si ao outro: "cada consciência, incapaz de envolver o mundo em todos os seus componentes espaciais e temporais, é limitada por sua ipseidade e não pode atingir o vivido de outras 'totalidades do mesmo tipo': ela está 'inteiramente isolada' e sem fusão possível com seus pares, pois permanece 'radicalmente' impenetrável".
} 
um ídolo a ser adorado - uma vez que ela o abandona, ou seja, corta o vínculo ontológico entre eles -, mas um ídolo a ser odiado: Baudelaire "põe-se em face deles na atitude do ressentimento, não da crítica", e "seu objetivo principal, que é o de castigá-los fazendo com que meçam a extensão de sua culpa, será alcançado quando ele os tiver feito contestar o abandono no qual o deixaram (...)" (SARTRE, 2012, p. 52). Continuar afirmando o caráter teológico dos pais - o que significa recursar superar o complexo teológico - é o recurso que Baudelaire encontra para não se deixar sucumbir totalmente pela terrível liberdade gratuita e injustificável: o outro, galvanizado por este caráter sagrado é, com isso, uma vacina contra o vírus da transcendência-não-justificável-e-contingente; através do olhar-sagrado-do-outro, o poeta quer "(...) realizar seu sonho de se sentir envolvido todo inteiro por um olhar. Mas, para que o julgamento que confere a Baudelaire seu lugar no universo seja sem recurso, é preciso, antes de tudo, que os motivos nos quais ele se inspira sejam absolutos". (SARTRE, 2012, p. 55). Separado de sua mãe-ídolo, o poeta experimenta o gosto de sua existência, de sua liberdade e, desta experiência, depara-se com sua total liberdade, mas amedrontado e angustiado por ela, escolhe, então, viver sob tutela, isto é, ter sua vida significada e sustentada pelo olhar do Outro. Entretanto, ele não poderia admitir ser o puro objeto desses olhares: na medida em que Baudelaire deseja gozar de sua singularidade como um puro objeto - como um serem-si -, seu orgulho não poderia satisfazer-se com uma originalidade aceita passivamente e da qual ele não fosse o autor: da mesma maneira que ele gostaria de objetivar o fluxo de sua vida intima, "ele procura interiorizar esta coisa que ele é para o outro fazendo dela um livre projeto de si mesmo" (SARTRE, 2012, p. 64). Doravante, diremos que Baudelaire, a partir de sua escolha original de si, encontrase divido entre o ser e a existência, o em-si e o para-si. Ele buscou fazer-se coisa perante o olhar de outrem, isso significa que ele desejou ser - e nós entenderemos com isso o modo de presença rigorosamente definida de um objeto -; ser sob a forma estática do em-si para gozar de si mesmo enquanto plenitude de ser, contudo, este ser não poderia ser dado enquanto pura passividade, uma vez que Baudelaire não deseja ser um puro dado do acaso: esta coisa que ele almeja ser "seria verdadeiramente sua, ela se salvaria se pudesse ser estabelecido que ela criou-se de si mesma e mantém-se por si mesma no ser" (SARTRE, 2012, pp. 74-75), ora e isto não é senão o modo de presença da consciência e da liberdade que, como Sartre, nomearemos existência. E é importante fazer notar que ele, Baudelaire, não deseja viver um ou outro até o fim, logo, trata-se sempre de viver no balanço contraditória entre o ser e a existência: quando se sente objeto (e objeto culpado) diante do olhar de seus juízes, ele trata imediatamente de afirmar contra eles a sua liberdade, porém, afirmando-a, ele encontra sua total gratuidade e, em sentido oposto, ele a mascara ao recolher-se neste mundo já feito no qual ele ocupa um lugar bem determinado; "ele escolheu possuir uma consciência perpetuamente dividida, uma má consciência" (SARTRE, 2012 , p. 75). Este balanço perpétuo entre ser e existência, ademais, é condição sine qua non da lucidez autopunitiva do poeta: se ele é objeto na medida em que aceita, sem nenhuma resistência, o julgamento e a condenação de seus inquisidores, esta livre aceitação, por outro lado, faz com que ele seja, igualmente, o seu próprio juiz. N’outras palavras, Baudelaire é a vítima e o algoz, o réu e o inquisidor, pois ao tratar-se com severidade a partir da moral já instituída, ele mesmo é o responsável 
por aplicar sua sentença; dessa maneira, ele busca fundir duas dimensões que não podem ser fundidas, a saber, a existência (para-si/consciência) ao ser (em-si/objeto): "esforço" inautêntico para "desequilibrar" transcendência e facticidade -.

IV

Embora seja certo de que este homem viva nos esquemas ardilosos da má-fé, é preciso lembrar, aqui, que isso não deve significar que ele esteja reflexivamente a par deste modo (inautêntico) de existência: na medida em que a escolha original de si é da ordem do vivido, quer dizer, da consciência irrefletida, ela é existida e não conhecida; Baudelaire não conhece sua escolha porque ambos são uma única e mesma coisa. Sob o veio deste olhar, não se trata também, como já suspeitemos, de uma escolhe inconsciente, pois "esta eleição de Baudelaire é sua consciência, é seu projeto essencial. (...) ele está tão penetrado por ela que ela como sua própria transparência. Ela é a luz de seu olhar e o gosto de seus pensamentos" (SARTRE, 2012, p. 76). Todavia, ainda que esta escolha seja da ordem do claro enigma, ou seja, da consciência irrefletida, Baudelaire possui a intuição dela (afinal, ela é seu próprio ser) e, no entanto, busca não crer nela: daí que sua escolha original seja, originalmente, de má-fé ${ }^{20}$. E se esta escolha de má-fé mostrou-se, até aqui, como um balanço perpétuo entre o ser a existência, esta revelação do projeto original de Baudelaire, seguindo os princípios metodológicos da psicanálise existencial, deverá ser constatada e observada em cada atitude/conduta empírica do sujeito analisado: é neste escopo que Sartre, reunindo cartas, poemas e outras biografias acerca do poeta, poderá, então, fortificar sua intepretação acerca de Baudelaire, e, finalmente, explicar (sempre a partir da hipótese psicanalítica do projeto original baudelairiano como balanço perpétuo do ser à existência) a versão que este possuía pela natureza, seu culto à artificialidade e à frigidez, o dandismo, etc. Contudo, é mister observar que esta escolha original (plano ontológico) complica-se infinitamente no plano ôntico (empírico) ${ }^{21}$, pois “cada pensamento, cada humor, diríamos um nó de víboras de tanto que comportam sentidos diversos e opostos, pois um mesmo ato pode ser querido por razões que se destroem umas às outras" (SARTRE, 2012, p. 94). Esta observação é salutar para aquele que pretende operar a "leitura" de um homem, isto é, para aquele que pretende, através da psicanálise existencial, apreender o homem em sua totalidade (destotalizada): a identificação da escolha /projeto original de si só será verdadeiramente aceita se ela puder explicitar/englobar o máximo de condutas possíveis no plano ôntico; ou seja, se ela puder oferecer, digamos, um campo interpretativo que faça com que compreendamos a totalidade das condutas empíricas do sujeito analisado; "nesse sentido, o biógrafo, de direito, jamais finda em descrever as condutas existenciais" (LOUETTE, 2002, p. 235). Pois bem, diz-se que a escolha original de Baudelaire é escolha (de má-fé) da existência e, ao mesmo tempo, do ser: de que modo, no plano ôntico, esta escolha exprime-se nas diversas condutas do poeta; ela é capaz, enfim, de explicá-las e reuni-las em um conhecimento

20 “(...) nesta escolha há a intenção de não se dizer, de abraçar todo conhecimento e de não se fazer conhecer. (...) Baudelaire não crê de fato em nada do que pensa, em nada do que sente, em nenhum de seus sofrimentos ou prazeres estridentes: eis aí, talvez, seu verdadeiro sofrimento" (SARTRE, 2012, pp. 76-77).

${ }^{21}$ A escolha original, “(...) no contanto da realidade, complica-se ao infinito" (SARTRE, 2012, p. 94).

FUJIWARA, Gustavo. Baudelaire: prolegômenos a toda biografia existencial sartreana futura. Griot : Revista de 
totalitário da singularidade deste homem? E é exatamente nesta perspectiva, portanto, que Sartre visará este "nó de víboras", quer dizer, as condutas baudelairianas. Incursionando esta investigação, demonstrar-se-á (como já dissemos, através de poemas e cartas), por exemplo, que o horror de Baudelaire à Natureza ${ }^{22}$, antes de figurar como fatura de sua formação cristã, advém de sua singularidade, singularidade moldada pela escolha original de si quando de seu traumático processo de individuação: seu horror ao natural e seus correlatos é devido, na ótica sartreana, de sua "intuição profunda desta contingência amorfa e obstinada que é a vida precisamente o inverso do trabalho - e ele possui horror disso porque ela reflete a seus olhos a gratuidade de sua própria consciência, gratuidade que ele almeja dissimular a qualquer custo" (SARTRE, 2012, p. 98). Intuindo a gratuidade do mundo natural, o poeta o rechaça em nome de uma existência justificada que encontra sua expressão máxima no trabalho do homem; 0 culto ao artificial significa, portanto, um culto a tudo aquilo que é da ordem do trabalho humano: para ele, a verdadeira água (água encanada) ou a verdadeira luz (luz elétrica) são aquelas provenientes das cidades, são realidades naturais moldadas e dominadas pelo trabalho; o que significa que elas deixam de ser coisas naturais para advir, então, como utensílios organizados segundo uma hierarquia e uma justificação: "A Natureza é o primeiro movimento, a espontaneidade, a imediatez, a bondade direta e sem cálculos, é, sobretudo, a criação inteira, húmus que ascende em direção ao Criador" (SARTRE, 2012, p. 108).

Se, por conseguinte, a Natureza representa o Bem, uma realidade que o circunda e se insinua a ele sem que ele tenha consentido, isso significa que ela manifesta a seus olhos a própria ambiguidade do Bem: um puro valor que se impõe a ele. Isso significa, n'outras palavras, que a Natureza, enquanto representante do Bem, sinaliza uma ordem moral que lhe é exterior; contudo, Sartre nota que a atitude de Baudelaire ao natural é ambígua - "o horror baudelairiano da Natureza casa-se com uma profunda atração" (SARTRE, 2012, p. 109) -, ambiguidade proveniente de um sujeito que escolhe, ao mesmo tempo, não ultrapassar as normas estabelecidas e nem, contudo, submeter-se totalmente a elas. Ora, esta conduta/atitude é a fatura direta da escolha primeira do poeta (balanço contraditório entre o ser e a existência): se ele se submete à moralidade dos Outros, esta submissão tem como função transformá-lo em coisa, afinal, "o ofício do olhar do Outro não é o de transformá-lo em coisa?" (SARTRE, 2012, p. 111), mas ele igualmente a rejeita em nome de sua liberdade, mas, ao rejeitá-la, depara-se com sua total contingência e volta a afirmar a moral que rechaça. Este jogo de vai-e-vem não passa senão da escolha primeira e de má-fé do poeta, qual seja, ser uma liberdade-coisa, liberdadesubstancial, em-si-para-si: "Seu desejo mais caro é ser como a pedra, a estátua, no repouso tranquilo da imutabilidade", mas, "que esta impenetrabilidade calma, esta permanência, esta adesão total a si seja precisamente conferida à sua livre consciência enquanto ela é livre e na medida em que é consciência (SARTRE, 2012, p. 157).

E desta escolha contraditória e impossível deriva, igualmente, seu famoso dandismo como esforço para mascarar sua gratuidade: as regras/máximas postuladas por este dândi são, antes de tudo, regras que visam frear sua indissolúvel liberdade;

22 “(...) o que ele chama Natureza, é a vida” (SARTRE, 2012, p. 100). 
"através de obrigações constantemente renovadas, ele mascará a si mesmo seu abismo: ele é inicialmente dândi por medo de si” (SARTRE, 2012, p. 124). Na medida em que Baudelaire intui que a vida espiritual não é dada, mas se faz, tal intuição o assombra e o lança na busca da possessão de si: "segurar-se, conter-se, é fazer nascer sob os dedos, sob os arreios, o si que queremos possuir. Desse ponto de vista, o dandismo é um episódio da empreitada perpetuamente fracassada de Baudelaire" (SARTRE, 2012, p. 125). Ademais, Sartre não deixa de notar que este dandismo baudelairiano é, também, uma defesa contra os outros (defesa contra sua timidez): sua limpeza sempre impecável e a meticulosidade de seus gestos são "o efeito de uma vigilância perpétua e representam uma recusa de jamais ser pego de surpresa: ele quer estar impecável sob os olhares" (SARTRE, 2012, p. 139). Mascaramento de sua liberdade e defesa contra os outros, a coquetterie baudelairiana traz, ainda, um terceiro sentido, qual seja, é um esforço para, através do olhar de outrem, recuperar-se. Se à seus próprios olhos o poeta não existe suficientemente, talvez seja possível que ele veja a si mesmo como os outros o veem, logo, trata-se sempre de buscar a si mesmo no olhar objetivante do outro; nesta toada, frisemos que o dandismo do poeta é um das tantas formas da díade ser-existência, carrascovítima, díade que busca superar a cissiparidade da consciência reflexiva: assim, Baudelaire "busca, mais uma vez, superar a contradição entre sua escolha de existir e sua escolha de ser: esse personagem que os espelhos refletem é sua existência enquanto ser, seu ser enquanto existência" (SARTRE, 2012, p. 144-45). Destarte, constatamos, ainda que en passant, que as condutas empíricas do poeta são e devem ser compreendidas a partir de seu projeto original de si, e é neste sentido, ademais, que se poderá falar da presente biografia como prolegômenos a toda biografia existencial: o que se revela aqui "é a estrutura de base dos textos biográficos de Sartre, uma estrutura ternária segundo a qual, após uma comédia que falha (no caso de Baudelaire, o amor com a mãe), uma liberdade é confrontada a escolher entre rebelião solitária e alienação submetida" (LOUETTE, 2013, p. 55). Além da observação, ver-se-á que Baudelaire inaugura um problema preciso em relação ao método psicanalítico-biográfico sartreano e que será constantemente desenvolvido, como veremos, nas demais biografias do filósofo (neste caso, em Mallarmé e, finalmente, em Genet); lemos:

Tal seria, em linhas gerais, o retrato de Baudelaire. A descrição que nós tentamos realizar aqui apresenta esta inferioridade acerca do retrato na medida em que ele é sucessivo no lugar de ser simultâneo. Somente a intuição de um rosto, de uma conduta, poderia fazer-nos sentir que os traços mencionados aqui um após o outro estão imbricados de fato em uma síntese indissolúvel onde cada um deles exprime ao mesmo tempo ele próprio e todos os outros. Bastar-nos-ia ver Baudelaire vivo, fosse por um instante, para que nossas observações dispersas se organizassem em um conhecimento totalitário [...] (SARTRE, 2012, p. 172).

Este excerto (aliás, importante para os rumos da biografia existencial) toca no problema da tensão pela qual é operado o conhecimento de um objeto (neste caso, Baudelaire) ausente no campo da percepção; o filósofo parece reconhecer a inevitável limitação de seu projeto, "pois nos quadros da psicanálise existencial, toda compreensão será de todas as maneiras sucessiva", logo, "adivinha-se que haverá 
sempre, em toda empreitada de compreensão por conceito, um hiato inevitável entre movimento e repouso: vê-se mal, com efeito, (...) como o sucessivo poderia alcançar a simultaneidade" (BOURGAULT, 2002, p. 52). N'outras palavras, como apreender a simultaneidade de um vivido, a vivacidade de uma presença já ausente do campo perceptivo? Destarte, "não vemos como a psicanálise existencial poderia, em suma, produzir a intuição de um projeto original de ser que é justamente simultâneo" (BOURGAULT, 2002, p. 52). O problema, ademais, fora mal formulado por nós: a simultaneidade do vivido não seria apreendida com mais rigor se, "fosse por um instante", pudéssemos ver ou encontrar Baudelaire vivo, pois "a percepção imediata é acompanhada, com efeito, de uma compreensão confusa e, para falar como Heidegger, "pré-ontológica', à qual seriam necessários vários anos para explicitar" (SARTRE, 2012, p. 172). Deste modo, Sartre reconhece que o que se dá na experiência bruta de um encontro é passível de compreensão, mas não é totalmente explicitada em um conhecimento totalizante uma vez que esta percepção imediata "contém, reunida em uma indiferenciação sincrética, as principais características do objeto" (SARTRE, 2012, p. 172); colocado nestes quadros, o problema toca na legitimação dos resultados da psicanálise existencial (quer estejamos ou não em presença do sujeito analisado). O comentador novamente: "Há uma intuição da presença - mas ela não pode ser produzida pela busca, "forçosamente sucessiva""; pois "toda lógica impõe uma cronologia: se a instantaneidade pode ser feita de mediações, assim como a simultaneidade, o fato é que as mediações não podem ser percorridas em um instante - e simultaneamente". Doravante, segue o comentador, "a psicanálise existencial, que propõe visar uma intuição da singularidade da existência, não pode ignorar que esta intuição não possa ser dada tal como se atesta uma presença" (BOURGAULT, 2002, p. 52). Ora, o que vemos aqui é, de alguma maneira, o problema acerca do conhecimento de um vivido em nível de reflexão: como conhecer aquilo que é da ordem da translucidez? Sob o veio deste olhar, Baudelaire é crucial para que possamos compreender um pouco melhor o modus operandi do método psicanalítico/biográfico sartreano; logo após expor este problema pontual, o filósofo não se furtará, todavia, de defender a possibilidade de um conhecimento totalizante do sujeito: "Em ausência desta compreensão imediata, nós podemos ao menos, para concluir, marcar a estreita interdependência de todas as condutas e de todas as afecções baudelairianas", isto é, "insistir sobre a maneira pela qual cada traço, por uma dialética singular, "passa' nos outros ou os deixa perceber ou os convoca para se completar (SARTRE, 2012, p. 172). Tentando, digamos, "remediar" o equívoco propiciado pela sucessão dos momentos de conhecimento, o conhecimento da singularidade "é interpelado para produzir um equivalente da intuição da presença - uma réplica, em suma, que somente aparecerá se soubermos insistir sobre os jogos de comparação que impõe o método" (BOURGAULT, 2002, p. 52). Para o comentador, portanto, a psicanálise existencial deve, através da insistência, suscitar uma espécie de esquema dinâmico e não uma forma conceitual através da qual uma personalidade seria dada de maneira estática em uma série de equações fechadas sobre si mesmas; mormente, trata-se, no método psicanalítico (insuflado pela dialética singular ${ }^{23}$ ), de comparar: "isso será, não alcançar o objeto de

23 “Em ausência dessa compreensão imediata, indica Baudelaire, possuímos a 'dialética singular' (...) que permite recompor um Baudelaire uno, apreender 'a estreita interdependência de todas as condutas e de todas as afecções 
maneira absoluta, em uma intuição - visão - dogmática, mas, constatando as diferenças e os pontos comuns entre os objetos de diferentes tipos, inventar uma compreensão particular" (BOURGAULT, 2002, p. 53).

Operando nesta insistência comparativa entre os diversos momentos do objeto (diferenças e pontos comuns), seriamos capazes de inventar uma compreensão particular do objeto analisado: n'outras palavras (e como já dissemos alguns parágrafos acima), é preciso observar atentamente as condutas empíricas do sujeito e testar a compatibilidade delas em relação ao projeto original. Insistamos, contudo, no inventar: não se trata, como se poderia presumir, de inventar uma compreensão alheia aos dados objetivos e precisos que possuímos do sujeito analisado (documentos, relatos, sua época histórica, etc, etc...), mas, precisamente a partir destes dados, inventar, quer dizer, criar uma maneira pela qual possamos compreendê-lo; daí que a psicanálise existencial, embora seja amparada por um método universal, seja, igualmente, a busca e a criação de métodos de compreensão forjados a partir da singularidade de cada indivíduo. Todavia, isso não significa que o método precise ser constantemente descartado de um caso para outro, mas que este método deve, a partir da singularidade do $\mathrm{X}$ analisado, reordenar-se de modo a apreendê-lo nesta singularidade: "inventar uma compreensão particular" indica, portanto, o fato de que cada individualidade requer um tratamento teórico "sob medida", logo, e isso já havíamos indicado, é preciso abrir mão de intepretações que generalizam os indivíduos entre si. Desta rápida observação, segue-se então a imagem deste método: a psicanálise existencial deve, a partir da realidade esquadrinhada ontofenomenológicamente, buscar compreender a maneira pela qual cada para-si individualiza-se nesta realidade; esta compreensão é resultante de um método que insiste na comparação das diversas condutas do sujeito, uma vez que cada uma dessas condutas simboliza a escolha original de si. Ademais, esta comparação, enquanto esquema dinâmico, resulta em uma dialética singular cuja démarche pode ser especificada da seguinte forma: "acompanhar os movimentos sucessivos de uma série de 'passagens' de uma significação a outra, de uma faceta a outra do real, acompanhamento no e pelo qual é atestada a mesma forma singular, a mesma modalidade do existir" (BOURGAULT, 2002, p. 55); trata-se, dessa forma, de desvelar a significação de cada conduta específica de modo a identificar, em cada uma delas, uma organização sintética que resulta, finalmente, do projeto original. Contudo, ainda é preciso fazer observar que esta dialética singular, em seu movimento, é marcada pelas contradições de uma existência (neste caso em tela a de Baudelaire):

[...] a negação de si 'passa na' afirmação de si como na dialética hegeliana, o suicídio torna-se um meio para perpetuar-se, a dor, a famosa dor baudelairiana, possui a mesma estrutura intima da volúpia, a criação poética aparenta-se à esterilidade, todas essas formas passageiras, todas essas atitudes cotidianas fundem-se umas nas outras, aparecem, desaparecem e reaparecem quando creríamos

baudelairianas'. Mas, esta dialética exige ser sempre complicada, conduz a uma exaustiva caça ao concreto, uma infinita investigação do gosto de um homem... Na biografia existencial a antropologia sartreana resolve-se em uma antropologia fantasiosa; o biógrafo sonha em comer seu objeto; mas permanece sempre com fome (...)" (LOUETTE, 2002, p. 236). 
estar longe delas; não são senão modulações de um grande tema primitivo que elas reproduzem com tonalidades diversas. Esse tema, nós o conhecemos, nós não perdemos de vista nem por um instante: é a escolhe original que Baudelaire fez de si mesmo. Ele escolheu existir para si mesmo como ele era para os outros, quis que sua liberdade lhe aparecesse como uma 'natureza' e que a 'natureza' que os outros descobriram nele lhes parecesse a emanação mesma de sua liberdade (SARTRE, 2012, p. 177).

Por conseguinte, é na apreensão desta dialética singular, com todos os seus momentos de contradição e multiplicidade de variações, que poderemos apreender o tema primitivo, isto é, a escolha original em torno da qual estas multiplicidades orbitam e estão unificadas. O "nó de víboras" - as condutas empíricas - expressa a escolha original de maneiras diversas, "mas essas variações são as condições mesmas para a compreensão de Baudelaire, pois todas elas remetem ao jogo de contradições que se encontra na má-fé, enquanto a contradição é mantida, não é ultrapassada, mas vivida em uma tensão" (BOURGAULT, 2002, p. 59). O método psicanalítico existencial, portanto, deve ser capaz de acompanhar essas contradições e não perdêlas de vista nem por um instante, ou seja, deve ser capaz de acompanhar o movimento (dialético) dessas contradições para, então, fazê-las convergir em um ponto de fuga comum (o projeto original); nesse sentido, é necessário evidenciar tais contradições para "mostrar que é em nossa maneira de mantê-las reunidas, simultaneamente, que inventemos nosso modo de ser, que escolhemos ser" (BOURGAULT, 2002, p. 59). Sobremaneira, esta evidenciação é operada através da escrita biográfica de Sartre ${ }^{24}$ : a escrita permitiria revelar o incessante jogo de contradições onde acompanhamos uma negação passar à outra, e assim manter, sem ultrapassá-la, uma tensão (estável); Bourgault (2002, p. 59), afirmando que a psicanálise existencial deve escrever-se, finda por concluir, então, que esta psicanálise é tarefa para o escrito-filósofo mais do que para o analista. Deste arrazoado de observações, podemos afirmar, portanto, que a psicanálise existencial, através da biografia existencial, deve ser capaz de produzir uma compreensão da singularidade de uma existência ao comparar as diversas tendências para, então, compreendê-las e agrupá-las à luz do projeto original. E não ficaríamos surpresos em constatar que estas indicações - ainda que elas figurem aqui em estado larvar e sejam insuficientes 25 - apareçam melhor explicitadas em Questions de méthode ${ }^{26}$. Lá, Sartre é mais claro e preciso em relação ao método progressivo-regressivo ${ }^{27}$ da biografia existencial:

\footnotetext{
${ }^{24}$ Bourgault (2002, p. 59) novamente: “A escrita, então, cuja tarefa é colocar em evidência da melhor maneira possível esta contradição, possui um papel decisivo".

$25 \mathrm{O}$ filósofo, em entrevista concedida para a revista New Left e, posteriormente, reeditada em Situations, IX (1987, p. 113), qualificará seu estudo sobre Baudelaire como insuficiente e até mesmo como "extremamente ruim". Nesse sentido, Baudelaire é um texto de transição, mas isso não impede que ele já não contenha posições filosóficas que, ulteriormente, serão repensadas e reorientadas por Sartre.

${ }^{26}$ Doravante abreviado como $Q M$.

${ }^{27}$ En court, nós poderíamos resumir o método progressivo-regressivo da seguinte maneira: em primeiro lugar, deve-se notar que este método é uma mistura de materialismo histórico (causas sociais, causas econômicas) e de psicanálise existencial (enquanto esta deve interpretar os projetos fundamentais do sujeito histórico). Segundo Flynn (2013, p. 219), o método progressivo-regressivo opera e implica três níveis: "ele começa por uma análise fenomenológica atenta da situação na qual o agente se encontra. Esta fase é a-histórica e descritiva. Em seguida, ele se desloca regressivamente rumo às condições de possibilidade desta situação segundo suas condições sociais,
} 
deixando de lado a discussão com os marxistas contemporâneos, poderíamos notar a indefectível influência de seu Baudelaire; partindo da obra do poeta, seríamos capazes de iluminar e esclarecer sua biografia, pois: "A obra coloca questões à vida. Mas é preciso compreender em que sentido: a obra como objetivação da pessoa é, com efeito, mais completa, mais total que a vida". Contudo, segue o filósofo, "é certo que a obra se enraíza nela, que a ilumina, mas só encontra sua explicação total nela mesma", logo, a vida é "esclarecida pela obra como uma realidade cuja determinação total se encontra fora dela, ao mesmo tempo nas condições que a produzem e na criação artística que a consuma e a completa exprimindo-a" (SARTRE, 1972, p. 90). Assim, a obra - torna-se hipótese e método de investigação para esclarecer a biografia, isto é, ela deverá interrogar e reter os momentos concretos como repostas às suas questões.

Entretanto, ainda que as questões suscitadas pela obra tragam interrogações acerca da vida do poeta, ela não saberia ser suficiente, pois este nível regressivo apenas desvela uma hierarquia de significações ainda heterógenas entre si (as condutas empíricas do sujeito analisado), uma vez que cada momento esclarece a outra, mas sua "irredutibilidade cria uma descontinuidade verdadeira entre elas; cada uma serve de quadro à precedente, mas a significação envolvida é mais rica que a significação envolvente" (SARTRE, 1972, p. 93). Nesse sentido, apenas o momento progressivo seria capaz de ordená-las em torno de um "movimento totalizador" que engendra cada momento a partir do momento anterior, e este movimento totalizador não é senão o que chamamos aqui de projeto original de si. E se $Q M$ traz uma série de conceitos que a presente biografia existencial em curso de análise não possui, isso, contudo, não impede que vejamos uma última influência desta sobre aquela: se aqui devemos insistir na comparação das diversas condutas para, então, inventar uma compreensão particular cuja veracidade será atestada na medida em que ela poderá englobar todas as condutas (passagem das condutas empíricas à escolha/projeto original), lá, da mesma maneira, "trata-se de inventar um movimento, de recriá-lo: mas a hipótese é imediatamente verificável: somente pode ser válida aquela que realizará, em um movimento criador, a unidade transversal de todas as estruturas heterogenias" (SARTRE, 1972, p. 93). Nesta perspectiva, o método biográfico de Sartre é capaz de apreender a multiplicidade divergente das condutas de um indivíduo para, então, revelar o "gosto de sua existência"; "gosto" que, como buscamos demonstrar aqui, não é linear/retilíneo, isto é, não passível de contradições. Se Baudelaire vive uma perpétua oscilação entre o ser e a existência, a passividade e a liberdade, vemos com clareza "as aspirações contraditórias que subentendem o texto sartreano: contra a biografia burguesa de Baudelaire ('ele não teve a vida que merecia'), insistir em sua responsabilidade e, portanto, em sua liberdade", mas, igualmente, "em virtude da leitura propriamente sartreana de Baudelaire, insistir em sua submissão à opinião do outro" (LOUETTE, 2002, p. 226). Sob o veio deste olhar, diremos, finalmente, que a plenitude de uma existência somente poderá ser apreendida através deste método psicanalítico-biográfico que, insistindo e comparando a miríade das condutas, chega a uma dialética singular que atesta o projeto/escolha original do sujeito: psicanálise existencial \& biografia

políticas, históricas em uma época dada. Então ele avança progressivamente, a partir de uma via psicanalítica, para determinar como o agente em questão vive essas condições e interioriza os eventos".

FUJIWARA, Gustavo. Baudelaire: prolegômenos a toda biografia existencial sartreana futura. Griot : Revista de 
existencial são, desse modo, duas faces de uma mesma moeda; e se se fala de Baudelaire como "prolegômenos a toda biografia existencial", isso possui sua razão de ser porque, antes de sua biografia monumental sobre Flaubert, já localizamos aqui (ainda que em estado embrionário) o objetivo de Satre de "mostrar um método e de mostrar um homem". 


\section{Referências}

ANSELMINI, Julie; AUCAGNE, Julie. "Présentation"; in: Recherches \& Travaux, n 71. Grenoble: Université de Grenoble, 2007, pp. 5-27.

2010

BOURGAULT, Jean. "La question de l'intuition dans l'élaboration de la psychanalyse existentielle"; in: ALTER, Sartre phénoménologue, $\mathrm{n}^{\circ} 10$. Paris: J. Vrin, 2002, pp. $43-64$.

COOREBYTER, Vincent de. Sartre face à la phénoménologie: Autour de "L'intentionnalité" et "La transcendance de L'ego". Paris: Éditions OUSIA, 2000.

FLYNN, Thomas R. "Histoire"; in: Dictionnaire Sartre. Sous la direction de François Noudelmann et Gilles Philippe. Paris: Éditions Honoré Champion, 2013, pp. 219-220.

LEIRIS, Michel. "Préface"; in: Baudelaire. Paris: Éditions Gallimard, "Folio Essais", 2012, pp. 11-16.

LOUETTE, Jean-François. Silences de Sartre. Toulouse: Presses Universitaires du Mirail, 2002.

. "Baudelaire"; in: Dictionnaire Sartre. Sous la direction de François Noudelmann et Gilles Philippe. Paris: Éditions Honoré Champion, 2013, pp. 54-55.

SIMONT, Juliette. "Dialectique"; in: Dictionnaire Sartre. Sous la direction de François Noudelmann et Gilles Philippe. Paris: Éditions Honoré Champion, 2013b, pp. 135-137.

SARTRE, Jean-Paul. L'être et le néant - Essai d'ontologie phénoménologique. Paris: Éditions Gallimard, "Tel", 2010.

. Baudelaire. Paris: Éditions Gallimard, "Folio Essais", 2012.

Situations, III. Lendemains de guerre. Paris: Éditions Gallimard, 1979.

Situations, IV. Portraits. Paris: Éditions Gallimard, 1993.

Situations, IX. Mélanges. Paris: Éditions Gallimard, 1987.

. L'Idiot de la famille. Gustave Flaubert de 1821 à 1857. Paris: Éditions Gallimard, 1971.

. "Questions de méthode"; in: Critique de la Raison dialectique; Tome I:

Théorie des ensembles pratiques. Paris: Gallimard, 1972.

Autor(a) para correspondência: Gustavo Fujiwara, Universidade Federal de São Paulo, Escola de Filosofia, Letras e Ciências Humanas, Estrada do Caminho Velho, n ${ }^{\circ} 333$ - Jd. Nova Cidade, CEP 07252-312, Guarulhos - SP, Brasil. fujiwaragustavo@gmail.com 